\title{
$\boldsymbol{\nabla}$ Artikkeli
}

\section{Konsensus-Suomea härnäämässä}

\section{Ylioppilaslehti 1980-luvun suomalaisessa julkisuudessa}

\begin{abstract}
Artikkelissa tarkastellaan Ylioppilaslehden kautta Suomen poliittisen ilmapiirin ja journalismin muutosta 1980-luvulla. Lehdellä on ollut ajoittain merkittävä rooli suomalaisessa julkisuudessa. Tutkimuskohteena on etenkin lehden suhde valtaapitäviin ja vaihtoehtoihmisiin uuden journalismin ja julkisuusteorioiden valossa. Artikkeli osoittaa, miten Ylioppilaslehden tapainen institutionalisoitunut mutta niin sanottu vapaa media reagoi paitsi 8o-luvun mediamaiseman, myös poliittisen sfäärin muutoksiin. Artikkeli näyttää, kuinka Ylioppilaslehti oli omalta osaltaan ja etujoukoissa kyseenalaistamassa konsensus-Suomea.
\end{abstract}

AVAINSANAT: uusi journalismi, julkisuus, 8o-luvun media, vaihtoehtoliikkeet

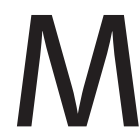
edia on aina ollut murroksessa, mutta ajoittain käänteet ovat olleet rivakampia. Näin esimerkiksi 1980-luvulla, jolloin suomalaisen median rakennemuutos ilmeni mediakentässä kaupallisten paikallisradioiden, kaapelija satelliittitelevision ja uuden urbaanin kaupunkilehtien tulona. Myös sanomalehdistö oli uudessa tilanteessa: puoluelehdet surkastuivat, markkinavetoinen kilpailu lisääntyi ja sanomalehdet keskittyvät. Kekkosen jälkeinen aika mahdollisti Suomessakin laveammin journalismin itsenäisyyttä - tilaa hengittää vapaammin kaikkeen puuttuvan vahvan presidentin jälkeen, YYA-Suomen bysanttisen liturgian jäädessä vähemmälle. Presidentti Koiviston ongelmallinen suhde mediaan edesauttoi instituutioiden välisiä konflikteja. Samalla suomalaiset, etenkin nuoret journalistit innostuivat subjektiivisesta uudesta journalismista.

Tässä artikkelissa tarkastellaan 8o-luvun poliittisen sfäärin ja journalismin muutosta Ylioppilaslehden kautta. Suomen suuriruhtinaskunnassa vuonna 1913 aloittanut lehti oli tuossa vaiheessa jo institutionalisoitunut nuoren sivistyneistön areena ja eliittihautomo, jonka toimituksen läpi oli kulkenut iso osa 190o-luvun suomalaisen politiikan, kulttuurin ja journalismin kermaa. Lehti oli hyvin tietoisesti luonut sukupolviajattelua' ja myyttisyyttään sotienvälisen oikeistoradikalismin propagan- 
damediumina, 50-luvun modernismin foorumina ja 60-luvun radikalismissa. 70-luvun ylioppilastoiminnan puoluepolitisoituminen oli merkinnyt selkeää taantumaa, josta haluttiin nousta. 8o-luvun tilanne, jossa mediakentälle ilmaantui uudenlaisia saman segmentin kilpailijoita, kannusti lehteä profiloitumaan. ${ }^{2}$

Ylioppilaslehteä voidaan pitää eräänlaisena ajankohtaisuuteen tukeutuvana järjestö-, kulttuuri- ja mielipidelehtien risteymänä, mutta vaikutukseltaan lehti on ollut luokitustaan merkittävämpi. Ylioppilaslehti ei ole ollut vain ylioppilaiden, yliopistoopiskelijoiden lehti. Ylioppilaat ovat aina olleet "aatteiden kolportöörejä" ${ }^{3}$ - heidän mielipiteensä ovat säännöllisesti murtautuneet ulos rajatusta tietynikäisten yhteisöstä. ${ }^{4}$

Ylioppilaslehti ei ole ollut tyypillinen lehti sarjassaan. Konkreettisesti tämä on ilmennyt levikissä, joka - etenkin valtakunnallisen jakelun aikana 1960-luvulta 1980-luvulle - on ollut huomattavasti suurempi kuin samankaltaisilla kilpailijoilla (parhaimmillaan noin 65 ooo). Myös julkaisijansa - ensin pääosin suomenkieliset osakunnat, sitten HYY - tarjoamassa toimitusvapaudessa suhteessa levikkiinsä sille ei löydy vertailukohtaa suomalaisen lehdistön historiasta.

Kuten Ylioppilaslehden 1980-luvun puolen välin toimitussihteeri Timo Harakka on todennut jälkeenpäin ajastaan lehdessä, heillä oli - kuten Orson Wellesillä tehdessään Citizen Kanea - maailman kallein leikkijuna: "Oli varma rahoitus ja levikki, joiden eteen ei tarvinnut tehdä mitään. Oli vapaus olla välittämättä lukijoista." Harakan mukaan se oli myös oikea tapa, koska "oli annettava uusia ajatuksia ja elämyksiä niille, jotka ovat avoinna sellaisille" (Grundström 1993, 63). Vaikka Ylioppilaslehdellä on opiskelija- ja kulttuurilehdeksi ollut varsin hyvät resurssit, on se kuitenkin ollut pienen toimituksen lehti, joka on ollut riippuvainen avustajistaan.

Ylioppilaslehden 80-lukua sekä lehden suhdetta valtaapitäviin ja politiikkaan tarkastellaan tässä yhteydessä journalismin aikalaistrendien ja julkisuusteorioiden valossa. Kiinnostuksen kohteena on etenkin lehden asema ja rooli uudessa suomalaisessa mediamaisemassa, jossa julkisuus muuttui ja sotienjälkeiseen konsensusajatteluun tuli provokatiivisia sävyjä. Artikkelin aineistot muodostavat pääosin Ylioppilaslehden 1980-Iuvun vuosikerroista - etenkin vuosista 1984-1987, jolloin lehti oli hyvin tietoisen postmoderni.

\section{Uutta journalismia}

Ylioppilaslehti on ollut tärkeä journalistien kouluttaja. Sillä on ollut esimerkiksi läheiset suhteet Helsingin Sanomiin jo lehden alkuvaiheista lähtien, vaikka "Erkon koulun jatkoluokka" ja "Hesarin haarakonttori" siitä tuli varsinaisesti 1980-luvun alussa. Eräänlaisena kulminaatiopisteenä voi nähdä vuoden 1982, kun Harri Saukkomaa valittiin Ylioppilaslehden päätoimittajaksi. Vaikka Saukkomaa oli entinen Jyväskylän Ylioppilaslehden päätoimittaja ja taustaltaan keskustalainen - kuten melkein kaikki Ylioppilaslehden 70-luvun poliittisesti valitut päätoimittajat - oli hän ennen kaikkea Sanomien toimittajakoulun kasvatti. 
Journalismin kehittäminen ja koulutus oli liittynyt Ylioppilaslehteen kuitenkin jo heti sotien jälkeen. Lehti muun muassa järjesti syksyllä 1947 oman reportterikurssin, jossa luennoivat ammattitoimittajat. Sanomalehtikoulutuksen aloittamisen ajaminen oli mukana oleellisesti myös Ylioppilaslehteä lähellä olleessa, vuonna 1947 perustetussa Ylioppilasneekerit-yhdistyksen ${ }^{5}$ - toiminnassa. ${ }^{6}$

Jakopoliittisen 70-luvun jälkeen 80-luvulla toimittajan ammattitaito muodostui poliittista sitoutuneisuutta tärkeämmäksi valintakriteeriksi Ylioppilaslehden toimituksessa. Myös lehden journalismi muuttui. Linjan muutos 80-luvulla oli hyvin tietoista ja suunniteltua, ja siihen kuului oleellisesti niin sanottu uuden journalismin suuntaus. Vuoden 1981 lehden ensimmäinen numero oli uuden journalismin teemanumero. Siinä haastateltiin muun muassa toimittajakoulun priimus Harri Saukkomaata, joka kaipasi journalismiin kokeiluja. Saukkomaan mukaan "uudet muodot tulevat lehdistä, jotka uskaltavat riskeerata, joilla on varaa olla tekemättä säännönmukaista ja turvallista lehteä". Hän näki, että toimittajan työ oli "väline maailman muuttamiseen". Numerossa haastateltiin myös hiljattain Tampereen yliopistossa väitellyttä Kauko Pietilää, joka korosti uuden journalismin subjektiivisuutta ja vertasi sitä taiteessa käytettyyn vieraannuttamiseen. Hän näkikin uusjournalistisen sanomalehden "teatterin näyttämönä". (Suvanto 1981; Hirvonen 1981.) Journalismin teoriassa alettiin tuolloin korostaa median konstruktiivista luonnetta; media tuottaa osaltaan todellisuutta määrittelemällä aiheet, näkökulmat ja käsittelytavat. Tähän liittyy ajatus, että median kuva todellisuudesta on aina rajoittunut tai vääristynyt. (Herkman 2009a, 45.)

"Uusi journalismi" (New Journalism)7 syntyi Yhdysvalloissa 1960-luvulla. Se oli eräänlainen romaanin ja journalismin rajoilla operoinut vastakulttuurinen journalismin kirjallinen suuntaus. Siinä missä ajan kirjallisuus saattoi olla ei-fiktionaalista, tositapahtumia kuvaavaa, journalismi mahdollisesti sisälsi sepitettyjä osia. Luonteenomaista uudelle journalismille oli myös subjektiivisuus; tekstit kirjoitettiin usein ensimmäisessä persoonassa. (Ks. esim. Muhlmann 2008.)

Yksi uuden journalismin suuntauksista oli niin sanottu gonzo-journalismi, joka oli päivän sana 1980-luvun alun Suomessa. Filosofi Esa Saarinen totesi hänen ja M.A. Nummisen Terässinfonia-kirjan ilmestymisen merkeissä tehdyssä Ylioppilaslehden haastattelussa (Palmgren 1980), kuinka gonzo-journalismi on "kirjallisuuden ylösnousemus, se on kommandoiskuja todellisuuden pätsinkuumassa viidakossa. Impressiot, tosiasiat, yliampuvat väitteet ja huumausainepilvessä nähdyt hallusinaatiot kierretään yhdeksi ainoaksi tajunannavirraksi." Tätä faktaa ja fiktiota yhdistävää ja omakohtaista kokemusta korostavaa journalismin muotoa viljeli tuolloin 80-luvun Suomessa etenkin Soundi-lehden toimittaja Juho Juntunen. Kansainvälisesti Gonzon perustajana pidetään muun muassa Tom Wolfea ja etenkin Rolling Stone -lehteen kirjoittanutta Hunter S. Thompsonia. Soundi-kirjat julkaisi Thompsonin artikkelikokoelman Suuri Hainmetsästys vuonna 1982. Kirjan julkaisua ennakoidessaan Ylioppilaslehti ennusteli suomalaisen journalismin muuttumisesta gonzoksi: 
Päätoimittaja saavat lukea uupumukseen asti sekopäisiä käsikirjoituksia, jotka on otsikoitu aitoon gonzo-tyyliin: Pelkoa ja inhoa Järvenpään sosiaalisairaalassa, Niuvanniemessä, Reeperbahnilla, Amsterdamissa jne., jne... Kaikki ei ole gonzoa, mikä kiitää. (Lindfors 1980)

Uusi journalismi oli ennen kaikkea perinteiseen ajankohtaisten ja faktapohjaisten joukkotiedotussanomien tuottamiseen perustuvan objektiivisen journalismin vastaista. Se ei noudattanut journalismin deontologista etiikkakäsitystä, jonka mukaan toimittajan velvollisuus on aina tuoda esiin totuus ja mahdollisimman paljon faktoja. Tällainen etiikka edellyttää myös, että toimittaja on lojaali vain jutulleen, eikä mieti tiedon julkaisemisen seurauksia. (Hemánus 1989, 21; Mäntylä 2008, 16.) Suomessa niin sanotun suomettumisen ${ }^{8}$ kontekstin vuoksi on hieman kyseenalaista todeta, etteivätkö toimittajat olisivat miettineet tiedon julkaisemisen seurauksia. 8o-luvun nuori toimittajapolvi sen sijaan saattoi periaatetta jo noudattaakin.

Vaikka uutta journalismia käsiteltiinkin paljon 80-luvun alun Ylioppilaslehdissä, se alkoi varsinaisesti näkyä lehden toimittamisessa vasta vuosikymmenen puolivälissä. Subjektiivisen journalismin taitekohta ilmenee kahden Ylioppilaslehden 8o-luvun toimittajan työssä. Peräti viisi vuotta Ylioppilaslehdessä työskennellyt ja sinne taistolaisten mandaatilla valittu toimittaja Jorma Lindfors totesi vuonna 1983 jäähyväishaastattelussaan (Pietinen 1983): "Lehdistössä on unohtunut tiedon välittämisen rooli, välitetään pikemminkin tunnelmia." Uudessa ajattelussa, johon Lindfors ei identifioitunut, journalismin katsottiin olevan maailmankuva. Tällaista viljeli etenkin Ylioppilaslehden toimittaja Kari Kontio, eräänlainen lehden 80-luvun narsistisen subjektivismin ruumiillistuma, joka haastatteli itseään nimimerkillä Christine Schildt vuonna 1984: "Mun tulkintani ei oo totta eikä valhetta, ne on vain elementtejä jutussa jonka voi tajuta vain henkilö joka on riittävän kiinnostunut mun taiteesta." (Pääk. 1984a; Shildt 1984.)

Vuonna 1983 Kontio kyseenalaisti tiedotusopin professorin Pertti Hemánuksen objektiivista journalismikäsitystä, mikä sai professorin vastaamaan syytöksiin lehden sivuilla (Kontio 1983; Hemánus 1983). Hemánus julkaisi yhdessä Ilkka Tervosen kanssa vuonna 1986 teoksen journalismin, todellisuuden ja yleisön suhteesta, jossa hän arvosteli etenkin "subjektivistisen illuusion" vallassa olevia toimittajia. Kirjan Ylioppilaslehteen arvostellut Tuomas Nevanlinna (1986) totesi kirjan olevan "osanotto Tampereen yliopiston tiedotusopin laitoksen käytäväkeskusteluun, jota on yritetty venyttää teorian suuntaan". Objektiivisen journalismin hylkääminen kuului myös vuonna 1985 perustetun Radio Cityn uudenlaiseen ajatteluun. Radiokanavalla se tarkoitti sitä, että juontajat esimerkiksi kommentoivat lukemiaan uutisia ja purkivat tunteitaan lähetyksissä (Isokangas ym. 2000, 21). ${ }^{9}$

Subjektiivisesta ja toisaalta tutkivasta journalismista tuli 80-luvun toimittajien juttu. Vaikka tyylilajit ja niiden tekijät saattoivat olla erilaisia, "yhteistä oli antiautoritäärisyys, individualismi, toimittajaromantiikka ja melkoinen ylimielisyys", kuten 80-luvun lopun Ylioppilaslehden päätoimittaja Saska Saarikoski (2010) totesi hiljattain toimittajasukupolvestaan. Kyse oli pitkälti muoti-ilmiöstä. Vuosikymmenen 
lopulla uusi journalismi alkoikin jo tuntua "tympeältä ja virkistävistä poikkeuksista" oli tullut "sameaa valtavirtaa" (Pääk. 1989).

\section{Valtionhoitajien kimpussa}

Subjektiivisuus yhdistyi usein auktoriteettien härnäämiseen, joka oli vapaampaa Kekkosen jälkeisessä Suomessa. Valtakunnallisesti uusi poliittinen mediasfääri (vrt. Herkman 2009b, 83-84) ilmeni esimerkiksi Tamminimen pesänjakajat (1981) pamfletissa, josta vastasi Helsingin Sanomien politiikantoimittajat salanimellä. Samana vuonna päättyi YLE:n uutismonopoli, kun MTV:n Kymmenen uutiset aloitti, ja TV1:n Hukkaputki-viihdeohjelma (1981-1983) toi poliittista satiiria televisioon. Edellisenä vuonna iltapäivälehtimarkkinat siirtyivät kilpailuun, kuin Iltalehti aloitti kilpailun Ilta-Sanomien kanssa. Suomalainen jour-

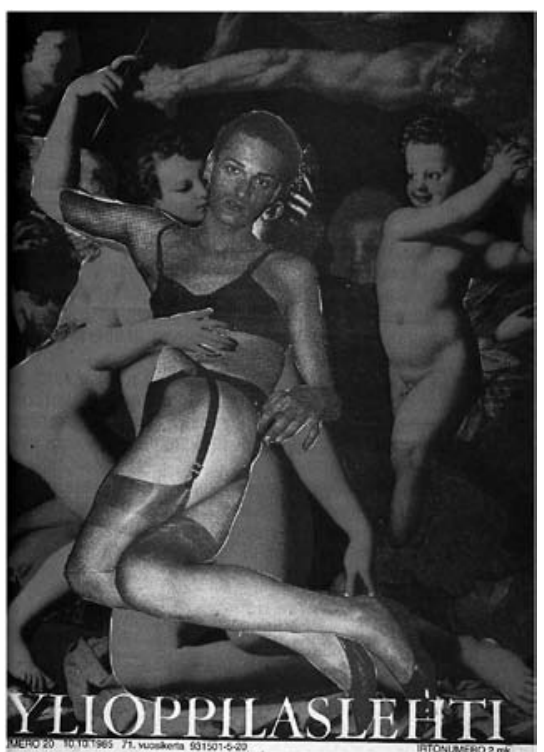

Ylioppilaslehti oli 1980-luvun lopulla postmoderneimmillaan. Tämä ilmeni niin sisällössä kuin lehden taitossa, joka villeimpinä aikoinaan teki lehdestä välillä hankalasti luettavan.

nalismi siirtyi uuteen aikaan, jota on luonnehdittu viimeaikaisessa suomalaisessa viestinnäntutkimuksessa (esim. Luostarinen \& Uskali 2006; Pernaa 2009, 199-279: Herkman 2011, 23; Kantola 2011) suomalaisen poliittisen journalismin käänteeksi, uudenalaiseksi politiikan julkisuudeksi, politiikan medioitumisen kiihdytysvaiheeksi ja vapautumisen ajaksi. 8o-luvulla siirryttiin jälkimoderniin tai "notkistuvaan" aikakauteen, joka koski niin journalisteja kuin poliitikkojakin.

Ylioppilaslehden rooli kaiken kyseenalaistajana lisääntyi 8o-luvun puolessa välissä voidaan jopa sanoa ärsyttämisestä tulleen itsetarkoitus. Enää lehdelle eivät riittäneet aikaisemmat sukupolvet. Nyt haluttiin ampua alas kaikkea mahdollista, jopa tasavallan presidenttiä ja Neuvostoliittoa. Kekkosen ajan jälkeen suomalaiset toimittajat yleisemminkin identifioivat ärhäkämmin itsensä vallan vahtikoiraksi, eivätkä alistuneet valtaa pitävien tiedottajiksi (Herkman 2009a, 39). 80-luvulla Suomi sai pitkästä aikaa kokea kahdet presidentinvaalit, joiden voittajaa ei oltu ennalta päätetty. Murros asennoitumisessa valtiollisiin auktoriteetteihin tulee hyvin ilmi esimerkiksi Ylioppilaslehden suhtautumisessa tasavallan presidenttiin.

Kun Ylioppilaslehden entinen päätoimittaja, mediaa kontrolloinut Urho Kekkonen väistyi, ja hänen tilalleen valittiin kryptisiä lausuntoja antava, mediaa vieroksuva Mauno Koivisto, oli maaperä altis valtiomahtien välisille konflikteille. Ylioppilaslehti sai uuden presidentin haastattelun lokakuussa 1982 (Saukkomaa \& Turkki 1982). Vaikka lehden voi sanoa olleen tottunut saamaan presidenttihaastatteluja, voi Koiviston myöntymisen katsoa lehdelle voitoksi. Koivisto oli antanut haastatteluja vain harvak- 
seltaan noudattaen valintapäivänään lehdistölle ilmoittamaansa niukkaa julkisuuslinjaa. Haastattelu, jonka päätoimittaja Saukkomaa oli tehnyt yhdessä avustaja Teppo Turkin kanssa, oli vielä varsin kunnioittava. Muutosta entiseen voi nähdä kuitenkin erillisessä pohjustusartikkelissa, jossa Turkki (1982) kuvailee haastattelutilannetta ja haastateltavaa, joka ei oikein tunnu istuvan Kekkosen luomaan presidenttiyteen.

Varsinaisesti kuvia alettiin kaataa pari vuotta myöhemmin, kun uuden journalismin sisäistänyt narsistinen, ironiaan ja sarkasmiin nojannut toimittajapolvi pääsi valtaan Ylioppilaslehden sivuilla. Koivisto oli lehden hampaissa etenkin vuonna 1985. Kirjoitettiin "Jari Komulaisen appiukosta", ja irvailtiin Koiviston ulkomaanmatkoista (Ytterström 1985a; Saarikoski 1985). Koiviston Assi-tyttären mies Komulainen oli lehden abi-numeron (4/1985) takakannessakin viinipullo kädessä. Etenkin presidentin Englannin vierailu oli ollut Koivistolle nöyryyttävä, koska hän oli joutunut odottamaan laivan kastamistilaisuudessa prinsessa Dianaa. Koska "julkisuus tuntui hylänneen lemmikkinsä" (Pääk. 1985a), Ylioppilaslehdessä haastateltiin demarivaikuttaja Risto Kolasta Koiviston suhteesta tiedotusvälineisiin. Kolanen totesi, että aika on toinen eikä Koivisto ole Kekkonen: Koivisto oli "epävarmuuden ajan presidentti". Kolasta Ylioppilaslehti ärsytti: "Nykyisellä 'kriitikkosukupolvella', joka selvästi edustaa jälkitaistolaista ideologiaresignaation vaihetta, ei näytä olevan mitään edellytyksiä ymmärtää työväentaustasta noussen presidentin ajattelua, eikä myöskään eri presidenttien luonnetta aikakausiensa kuvaajina" (Tirkkonen 1985).

Presidentille irvailtiin monesta asiasta. Eräs Koivistoon kohdistunut kritiikki koski hänen armahduskäytäntöään, jonka nähtiin suosivan poliitikkoja ja muita "herroja". Koivisto esimerkiksi armahti vuonna 1987 terveydellisistä syistä oululaisen kokoomuksen oikean siiven kansanedustajan Eero Lattulan, joka oli tuomittu törkeästä veropetoksesta. Ylioppilaslehti julkaisi ilmoituksen muutaman vuoden takaisesta sanomalehti Kalevasta, jossa Lattulan Vaalityöyhdistys ilmoitti, kuinka Lattula oli voittanut jo kuudennen kerran parlamentaarikkojen hiihtokisoissa: "Ylioppilaslehti toivottaa heikkokuntoiselle Eero Lattulalle pikaista paranemista. Samalla kiitämme Tasavallan Presidenttiä rohkeasta päätöksestä antaa armon käydä oikeudesta tälläkin kertaa." (YL 21/1987.) Kilpailut oli järjestetty Mauno Koiviston Holmenkollen-vierailun siivittämänä.

Koivisto saatiin myös reagoimaan, mutta siihen tarvittiinkin jo sitä kaikkein pyhimmän rienaamista. Vuonna 1985 Ylioppilaslehti kirjoitti Neuvostoliiton puoluejohtaja Konstantin Tšernenkon sairastumisesta ja toivotti hänelle pikaista paranemista. Todellisuudessa Tšernenko oli jo kuollut edellisellä viikolla. Hänet oli kuitenkin nähty äänestämässä hiljattain, kuten Suomenkin lehdissä uutisoitiin. Ulkomaiset lehdet olivat osoittaneet asetelman lavastukseksi: sairaalahuoneesta oli tehty vaalihuoneisto. Tšernenkon käsitteleminen neuvostojulkisuudessa yhdistettiin Ylioppilaslehdessä - Suomea tai Kekkosta mainitsematta - muutaman vuoden takaiseen Suomen tilanteeseen, jolloin presidentin terveydentilasta vaiettiin: "Aijai, semmoista se on totalitarismissa" (Pääk.1985b). Samalla sivulla pakinanimimerkki Ytterström (eli Asser Korhonen; Ytterstöm 1985b; ks. myös Harakka 1998, 22-23) yhdisti Neuvostoliiton johtajan kuoleman ajankohtaiseen kehitysmaiden hyväksi järjestettyyn kampanjaan: "On toistaiseksi vielä epäselvää, kuoliko Konstantin Tshernenko nälkään vai nälkätempaukseen." Kirjoitukset herättivät jon- 
kin verran julkisuutta. Kommunistilehdet paheksuivat, ja poliitikot varoittelivat jopa lehdistön "kuriinpanosta". ${ }^{\circ}$

Koivisto paheksui samoihin aikoihin eräässä puheessaan yhteiskunnassa esiintyvää neuvostovastaisuutta ja mauttomia ylilyöntejä. Presidentin puhe tulkittiin pitkälti Ylioppilaslehden jutuista johtuviksi. Lehden tuolloinen vt. päätoimittaja Timo Harakka katsoi Koiviston loukkaantuneen "omasta puolestaan, ja koko salaseuran, joka on häikäilemättä hallinnut kuolevan miehen selän takaa". (Harakka 1998, 22-23; Kimmo Pietisen haastattelu; Grundström 1993, 63.)

Lehti oli aiemmin ruotinut varsin ennenkuulumattomalla tavalla Neuvostoliiton johtajavaihdoksia ja niihin liittyvää valtapeliä Kremlissä:

Ja miksikö Ylioppilaslehdessä pitäisi spekuloida idän vahakabinetin pöllyämistä? Totta helvetissä meitä kiinnostaa suuren ja ystävällismielisen naapurimme nuorison ponnistelu valtakunnan rauhapolitiikan johtotehtäviin. Yksinkertaista. (Pietinen 1984a)

Satiiri oli kuulunut Ylioppilaslehden ärsyttämisarsenaaliin jo melkeinpä lehden alkutaipaleilta lähtien. Lehden sivuilla oli aloittanut moni legendaariseksi noussut pakinanimimerkki, jonka kirjoitustyyli oli usein satiirista (esim. alkuvuosien Olli eli Väinö Nuortimo tai 6o-luvun alun Nenä eli Pentti Saarikoski). Samoin piirrokset ja sarjakuvat ovat olleet oleellinen osa Ylioppilaslehden historiaa. 8o-luvun piirtäjistä (Harri) Pystynen vei satiirin aivan uusille, usein nihilistisille tasoille, joissa poliitikotkin saivat osansa. Satiirien tavoitteena on poliittisissa skandaaleissakin usein paitsi ärsyttää myös tervehdyttää yhteiskunnan toimintarakenteita (Kivistö 2011, 143). Tämä pyrkimys tuli ilmi suoremminkin 8o-luvun Ylioppilaslehdessä.

Ulkopolitiikan käsittely suomalaisessa mediassa oli rivien välistä luettava arka aihe vielä Koivistonkin aikana (Luostarinen \& Uskali 2006, 181-182). Toisaalta Koivisto oli tietyllä tavalla otollinen ärsyttämiskohde, koska presidentin suhde mediaan osoittautui hänen ensimmäisellä kaudellaan vaikeaksi. ${ }^{1 "}$ Tämän on ristiriidassa sen kanssa, että Koivistoa on pidetty "television hellimänä" ensimmäisenä media-ajan presidenttiä (Herkman 2011, 23). Vaikka Koivisto oli jo 1960-luvun lopun pääministeriaikanaan valloittanut tv-katsojia otsakiehkuroineen Jatkoajassa sekä tietyllä tavalla arkistanut suomalaisen poliitikon kuvaa, oli hänen suhteensa mediaan presidenttikausinaan suuresta suosiosta huolimatta problemaattinen. Käsitys "ensimmäisestä media-ajan presidentistä" on myös siinä mielessä harhaanjohtava, että Kekkosta on yleisesti pidetty hyvin taitavana median käyttäjänä. Vaikka suomalainen mediakonteksti muuttui 8o-luvulla, ei televisio ollut Koiviston aikana oleellisesti erilainen kuin Kekkosenkaan aikana - kuten ei presidentin asemakaan.

Tammikuussa 1984 Koivisto kutsui toimittajia sopuleiksi, jotka kulkevat laumoina saman aiheen perässä. Ylioppilaslehden tuolloinen päätoimittaja Kimmo Pietinen (1984b) näki Koiviston lausunnon osaksi suomettumisilmiötä: "Jos Koivisto joutuukin 'länsimaisen' 'demokratian' sananvapauden nimissä sietämään, että lehdistö häntä selittelee, on hän ajatellut, että alaisiltaan sen ainakin voi kieltää." Seuraavana vuonna lehti (Mäntyranta 1985a) arvosteli Koiviston ulkopolitiikkaa vain itään suuntautuvaksi 
ja vertasi Koivistoa edeltäjäänsä: "Kun Kekkonen otti rohkeasti kantaa vähäosaistenkin puolesta oman etiikkansa mukaan, on Koivisto tasapainotellut populismin ja eliitistä huolehtimisen välillä."

Samana vuonna 1985 Koivisto suuttui Yleen, joka siteerasi hänen lausuntoaan väärässä yhteydessä mahdollisesta asettautumisesta ehdokkaaksi seuraavissa presidentinvaaleissa. Tämä niin sanottu sitaattikiista äityi instituutioiden väliseksi kriisiksi, jonka vuoksi presidentti antoi jonkin aikaa haastatteluja vain MTV:Ile. Edellisenä vuonna pääministeri Kalevi Sorsa oli puhunut SDP:n puoluekokouksessa "infokratiasta". Sorsa syytti tiedotusvälineitä epäolennaisuuksista ja -älyllisyydestä. Sorsan mielestä tiedostusvälineet eivät kirjoittaneet yhteiskunnallisista ongelmista vaan keskittyivät pinnallisiin asioihin. Ylioppilaslehti kutsui näitä Sorsan ja Koiviston tarkoittamia politiikan toimittajia "politiikan vahtihauvoiksi" (Aleksanda K. 1985). Syksyn 1985 eräänlaisessa politiikka-numerossa (21/1985) arvioitiin niin Koiviston kuin Sorsan politiikkaa ja suhdetta julkisuuteen.

Kun Koivisto yritti vuonna 1987 luoda parempia suhteita tiedotusvälineisiin järjestämällä saunailtoja valikoituneelle toimittajaryhmälle, Ylioppilaslehden päätoimittaja Eero Hyvönen kirjoitti odottavansa kutsua säännöllisiin ja julkisiin presidentin kyselytunteihin (Pääk. 1987). Myös Sorsan seuraaja SDP:n puheenjohtajana, Pertti Paasio, syytti Yleä "likasankojournalismista". Eräs näistä toimittajista, joita Ylen hallintoneuvostoon kuulunut Paasio tarkoitti, oli Juha Hemánus. Hemánus (1988) kirjoitti Ylioppilaslehdessä, kuinka kyse oli "lingvistisestä, semioottisesta ja filosofisesta yhteentörmäyksestä vallanpitäjien kanssa". ${ }^{2}$ Valtionhoitajapuolue SDP:tä, kuten koko vasemmistoa, ruodittiin Kari Kontion ja Hannes Mäntyrannan (1986) pitkässä esseessä helmikuussa 1986: "SDP on johtajavaltainen ja epä-älyllinen organisaatio." Tietoyhteiskunnan kapitalismi oli "tappanut sosialismin ihanteet massoilta". SDP:n, "tuon harmittoman frendin" olemassaolo edellytti valheita. Demarilehdet katsoivat Ylioppilaslehden vajonneen lokajournalismin suohon (Savolainen 1986). Numeron tiimoilta Ylioppilaslehden toimitus levitti kaupungille yön tunteina vaaleanpunaisia "lööppejä" - tiettävästi ainoita lehden historiassa - joissa huudettiin: "SDP:n petos paljastuu". Samoihin aikoihin Kontio ohjasi Teatterikorkeakoulussa Timo Harakan ja Kai Raumosen käsikirjoittaman näytelmän Sorsa Pariisissa ('Teatterikoulu esittää' 1986).

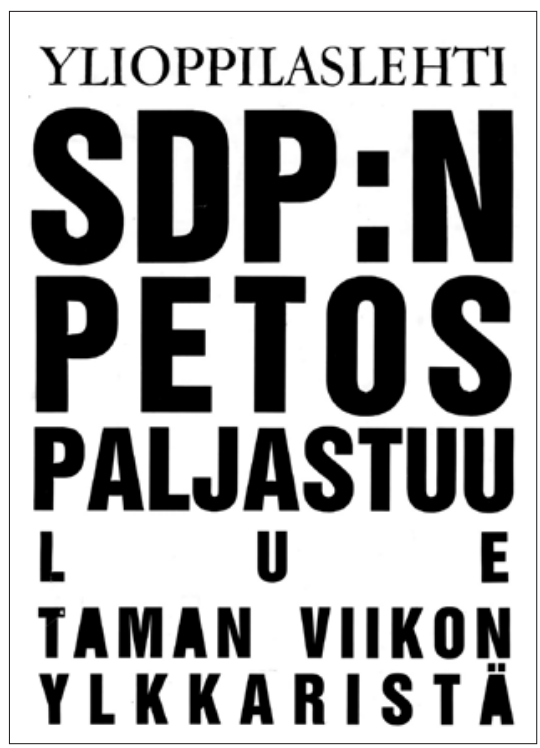

Vuonna 1986 Ylioppilaslehden hampaissa oli valtionhoitajapuolue SDP. Numeron ilmestymisen yhteydessä toimitus levitti kaupungille yön tunteina vaaleanpunaisia lööppejä. 
8o-luvun viimeinen konflikti presidentti-instituution ja Ylioppilaslehden välillä syntyi vuonna 1988, kun lehti sai taas tasavallan presidentti -haastattelun. Kysymykset piti lähettää kolme viikkoa etukäteen presidentin kansliaan, jolloin Koiviston ongelmalliset suhteet tiedotusvälineisiin tulivat ilmi. Etukäteen ilmoitettiin se mahdollisuus, että haastateltava saattaa tarkentaa lausuntojaan jälkikäteen, ja haastattelu on julkaistava haastateltavan haluamassa muodossa. Näin myös tapahtui. Tasavallan presidentin erikoisavustaja Martti Manninen kirjoitti jutun kokonaan uusiksi. Manninen oli myös laitettu jutun kirjoittajaksi, kun se julkaistiin presidentinvaalivuoden 1988 ensimmäisessä numerossa otsikolla "Tasavallan Presidentin virallinen haastattelu" (M. Manninen 1988). Toimitus julkaisi oman versionsa jutusta seuraavassa numerossa. (Kantola 1988; Tunkkari 1988.)

Ylioppilaslehden pääkirjoitus palasi vielä Koiviston haastatteluun seuraavassa numerossa, jossa käsiteltiin Uuden Suomen haastattelun pohjalta tekemää tulkintaa, että kysymyksessä oli "syvä kuilu" Ylioppilaslehden nuorten polven - jotka ovat "historiattomia ja pinnallisia city-nuoria" - ja presidentin välillä. Tämän huomion toimitus katsoi oikeaksi, mutta totesi kuilun olevan suhteessa kaikkiin politiikkoihin. Kuiluun oli haastattelussa pudottu alusta lähtien: "Kun me yritimme puhua tulevaisuudesta, Koivistoa kiinnosti menneisyys; kun yritimme urkkia visioita, Koivisto halusi tarjoilla takautumia politiikkansa saavutuksista." (Pääk. 1988.)

TV 2:n Ajankohtainen Kakkonen (1989) vertasi Ylioppilaslehden Koivisto-haastattelun käytäntöä Kansan Uutisten samoihin aikoihin Romanian diktaattori Ceausescusta tehtyyn haastatteluun. Sille olivat "nauraneet naurismaan aidatkin", koska kysymykset, vastaukset, muotoilu ja oikeinkirjoitus olivat kaikki Ceausescun kanslian käsialaa. Ohjelmassa haastateltu Ylioppilaslehden päätoimittaja Saska Saarikoski totesi: "Kansan Uutisten Ceausescu-haastattelu oli minusta erinomaisen pirteää journalismia verrattuna $90 \%$ :iin niistä jutuista, joita presidentti Koivistosta viime vaalien alla tehtiin." Saarikoski muisteli myöhemmin, ettei heidän ratkaisunsa julkaista myös oma versio lopulta saanut kovin paljon julkisuutta, vaikka tarkoitus oli eittämättä ollut herättää huomiota. Jonkin verran ilmeisesti yleistyi sanonta kokea "manniset", jos lehdet joutuivat samantyyppisen korjailun kohteeksi. ${ }^{13}$ Toisaalta aikojen muuttuminen, jolIoin "on jäljellä vain täydellinen sananvapaus", oli turhauttavaa: Kaikkien juttujen oli "lunastettava itsenä jotenkin erityisesti" tai muutoin kukaan ei kuunnellut, kuten Saarikoski totesi jo vuonna 1988. (Saska Snellmanin haastattelu; Mattila 1988.) Postmoderni aika tai "notkistuva moderni" siis itsenäisti, kuten Anu Kantola (2011, 125-134) on todennut, mutta teki myös hätkähdyttämisestä vaikeampaa. Edellisen valossa tutkija näyttäisi perustavan käsityksensä myös omaan toimittajakokemukseensa.

\section{Vaihtoehtojulkisuutta}

Koivisto ja demarit eivät tosin olleet ainoa poliittinen taho, jonka toimintaa kyseenalaistettiin. Myös opiskelijanuorisoa lähellä ollut vihreä liike sai osansa uudesta vapaammasta ilmapiiristä ja subjektiivisesta journalismista. Ylioppilaslehden "terävät 
ja häikäilemättömät" vaativat kriittisyyttä myös omaa sukupolveaan kohtaan, ettei hyysättäisi käenpoikasta (Pääk.1984b). Ylioppilaslehti kirjoitti syksyllä 1984:

Mutta miksi valtaanpyrkijöiden ja toimittajien välillä pitää vallita luottamus ja harmonia? Miksi kaiken karvaisten vihreitten, naisten rauhaliikkeiden luonnonsuojelijoiden pitää saada niin hampaaton kohtelu." (Ytterström 1984)

Etenkin 1980-Iuvun puolenvälin toimitussihteeri Timo Harakka'4 kirjoitti paljon vihreän liikkeen kivuliaasta tiestä puolueeksi ja vihreiden laajemmastakin merkityksestä suomalaisessa poliittisessa kulttuurissa (ks. esim. Harakka 1983; Harakka 1984a). Harakka totesi jälkeenpäin, että he katsoivat vihreiden alakulttuuria nenänvartta pitikin: "Meillä oli tämä kriittinen näkökulma kaikkeen. Ne taas pitivät meitä toisia vittumaisina jätkinä." Harakalle ja Ylioppilaslehden avustaja-ironikoille Kari Kontiolle ja Asser Korhoselle vihreät näyttäytyivät lian "vaarattomina" ja tosikkomaisina: "Ja pitkäpiimäisinä: istuvat kaiket illat villakukkasillaan purkutaloyhteisön lattialla suunnittelemassa seuraavia kokouksia, joissa istutaan villakukkasillaan yhteisön lattialla." (Grundström 1993, 63; Harakka 1998, 22.)

70-luvun lopun Koijärvi-liikkeestä alkanut vihreä liike oli kuitenkin yhdessä sitä sivuavien vaihtoehtoliikkeiden kanssa tärkeässä osassa 80-luvun Ylioppilaslehdessä. Kaiken kaikkiaan aika nosti kansalaisjärjestötoimintaa, joiden pohjalta monia eri asioita ajavat inmiset saattoivat toimia yhden liikkeen suojissa. Monet liikkeessä alusta

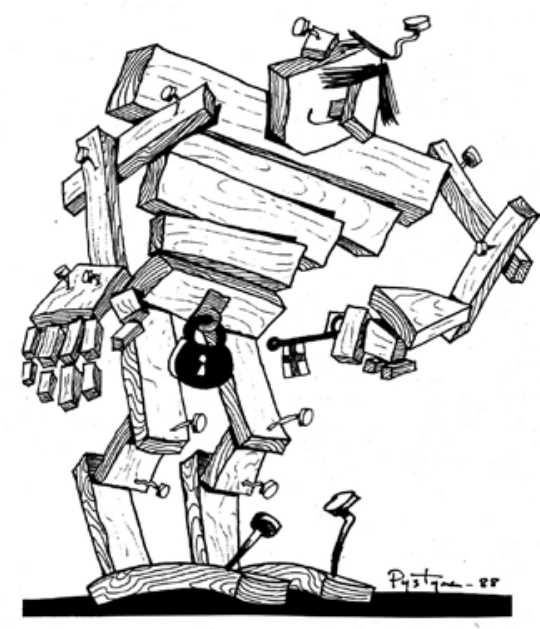

Erotiikan ja seksin käsittely oli suosittua Ylioppilaslehdessä 80-luvulla. Seksi assosioitiin jopa presidentti Koivistoon, joka oli vuoden 1988 haastattelun yhteydessä todennut Ylioppilaslehden toimittajille hyvän kirjan saattavan olla paitsi esteettinen, myös eroottinen kokemus. Harri Pystysen palkittu Pystynen-sarjakuva viilsi aikaa nihilismin ja ironian terällä. mukana olleet kutsuivat itseään lähinnä vaihtoehtoihmisiksi. Suomalaisen vihreän liikkeen alkuvaiheissa siinä ja sen liepeillä toimi paitsi rauhanliikkeen aktiiveja, myös vammaisia, seksuaalivähemmistöjen edustajia, kasvissyöjiä, ELMUlaisia jne.

Leimallista 8o-luvun Ylioppilaslehdelle oli erilaisten - ainakin jossain määrin vielä - tabuaiheiden käsitteleminen, jota ei löytynyt valtalehdistä. Toki esimerkiksi seksuaalisuudesta, uskonnosta, armeijasta ja huumeista oli Ylioppilaslehdessä kirjoitettu jo 6o-luvulla, mutta nyt niistä tuli vakioaineistoa. Aiheita lähestyttiin varsin perinpohjaisesti ja monesta suunnasta. Myös uusi journalismi ja postmoderni ajattelu loivat alustaa uudenlaisille lähestymistavoille, joissa kyseenalaistettiin totuttuja käytäntöjä.

Seksuaalisuuden käsittelyssä 8o-luvun Ylioppilaslehden voidaan sanoa toteuttaneen "mitä ylioppilaat tänään, sitä kansa huomenna" -ajattelua. Feminismin aloittama keskus- 
telu, jossa Ylioppilaslehti oli hyvin aktiivinen, eteni 8o-luvun aikana laveampaan kirjoitteluun seksuaalisuudesta ja sukupuolesta. Varsinkin homoseksuaalisuudesta kirjoitettiin, olihan 80-luku AIDS:n tulon vuosikymmen.

Jo ennen tämän aluksi "homotaudiksi" leimatun sairauden tuloa julkisuuteen Ylioppilaslehdessä kyseltiin "mahtuvatko homot kirkkoon?" Artikkeli liittyi vuoden 1983 helmikuussa Helsingin tuomiokirkon kryptassa pidettyyn teemajumalanpalvelukseen, jonka järjestivät Homoseksuaalien kristillinen piiri ja evankelis-luterilaisten seurakuntien korkeakoulutyö. Tilaisuus aiheutti rajua paheksuntaa kirkon piirissä, ja siitä keskusteltiin myös teologisessa tiedekunnassa, jossa mielipiteiden kirjo vaihteli laidasta laitaan: "Taipumus ei ole väärin, mutta homoseksuaalinen teko kyllä [...] Homot voivat parantua harhastaan Jumalan avulla." Ylioppilaslehdessä haastateltiin nelikymppistä kristillistä naisparia, jotka olivat olleet yhdessä viisitoista vuotta. Oikeilla nimillään esiintyneet naiset kertoivat muun muassa, että "ainoastaan 1200-luvulta lähtien on kristillisessä ajattelussa homoseksuaalisuutta pidetty syntinä". Jutussa kerrottiin myös homoseksuaalien kristillisen piirin syntyneen jo 1970-luvun alkupuolella. Homojen syrjiminen nähtiin osana vähemmistöihin kohdistuvaa syrjimistä: "Mitä on olla vähemmistön vähemmistö: uskova homoseksuaali?" (Heino 1983.)

Ylioppilaslehti julkaisi seksuaalisuudesta kaksikin laajempaa teemanumeroa 1980luvun puolessa välissä. Loppuvuonna 1984 kirjoitettiin etenkin lapsen seksuaalisuudesta ja pornosta, mutta myös opiskelijaprostituutiosta. Viimeksi mainitun teeman yhteydessä toimitussihteeri Harakka teki tutkivaa journalismia yliopistokaupunki Jyväskylässä - heikoin tuloksin. Lehdessä kirjoitettiin, kuinka Yhdysvalloissa feministit ja ultrakonservatiivit olivat liittoutuneet sodassa pornoa vastaan. Suomalaisesta pornosta todettiin: "Pornossa ratkaisevat kysynnän ja tarjonnan laki: suomalainen kansanmies haluaa Kallensa rasvaisena. Kun ainoa moraali on kukkarossa, jäljelle jää vain märkä vittu." Lasten seksuaalisesta hyväksikäytöstä kirjoittamisessa Ylioppilaslehti oli eittämättä edellä aikaansa ja alueella, joka oli vielä alleviivatun tabu: "Aihe on kuitenkin edelleen siinä määrin ahdistava monille terveydenhoitoalan työntekijöillekin etteivät he toisinaan tiedä miten suhtautua. Näin seksuaalisen hyväksikäytön osapuolet voivat edelleen jäädä hoitamatta." (Väliverronen 1984; Lähteenmaa 1984; Harakka 1984b; Kirstinä 1985; Hänninen \& Rutanen 1985; Rutanen 1985; Pääk.1985C.)

Vuonna 1986 julkaistiin seuraava seksuaalinumero, joka oli teemanumero paitsi erotiikasta myös kuolemasta. Päätoimittaja Hyvönen kertoi lapsen seksuaalisuudesta oman lapsuutensa kautta, ja Suvi-Anne Siimes kirjoitti yksityiskohtiin paneutuvan jutun raskaana olevan naisen sukupuolielämästä, joka päättyi siihen kun "valkoinen maito kasteli miehen hajallaan olevat hiukset". Etenkin yhteiskuntatieteissä tuolloin suosittu "ruumiillisuus" ilmeni jutuissa. Eeva Pyörälä kirjoitti intohimoisesta ja seksuaalisesta ruumiista, ja Jari Ehrnrooth erotiikan ja estetiikan suhteesta Bourdieun makuerottelujen viitekehyksessä. Johanna Mäkelä tutustui harlekiinikirjallisuuden pornografiaan. Lehden toimitus taas valaisi erotiikan ja esineiden suhteesta, seksioppaista sekä selibaatista ja masturbaatiosta AIDS-hysterian aikana. Lisäksi esiteltiin "pornotologisista" teksteistään tunnettu ranskalainen "filosofi" ja taiteilija Georges Bataille, jonka teksteissä seksi liittyi usein kuolemaan. Samassa numerossa vierailtiin 
myös krematoriossa ja egyptiläisessä kuolleiden kaupungissa. Joukko lahtelaisia kristittyjä kanteli numerosta oikeuskanslerille, mutta kantelu ei johtanut toimenpiteisiin. (Hyvönen 1986; Siimes 1986; Pyörälä 1986; Ehrnrooth 1986; Mäkelä 1986; Nyberg 1986; HYY:n vuosikertomus 1986, 41.)

Ylioppilaslehti antoi runsaasti tilaa myös aseistakieltäytymisen käsittelylle. Euroohjusten alaisen ydinaseidenvastaisen liikkeen ja uudelleen järjestäytyneen rauhanliikkeen luomassa ilmapiirissä yleinen asevelvollisuus ja etenkin sen vastustaminen nousivat varsin suosituksi aiheeksi Ylioppilaslehdessä 8o-luvun puolessa välissä. Siviilipalvelus ja totaalikieltäytyminen liittyivät eittämättä myös Kekkosen jälkeisen ajan vapautumisen ja individualismin ilmapiiriin asevelvollisten ja laajemminkin nuoren älymystön keskuudessa.

Aseistakieltäytyminen oli osa 8o-luvun uusia liikkeitä, joihin kuului muun muassa se, että henkilökohtainen poliittisuus korostui. Kuten Siviilipalvelusmiesliiton Sivari-lehden päätoimittaja ja opiskelija-aktiivi Ilpo Helén totesi, aseistakieltäytyminen oli "kulttuurija elämäntapajuttu". Se oli "henkilökohtainen ratkaisu, yhteiskuntanäkemyksen privatisoitumisesta 'sekä hyvässä että pahassa'”. (Harakka 1985, 19.) Aseistakieltäytymiseen liittyi etenkin amerikkalaisen Henry David Thoreuaun 1840-luvulla lanseeraama idea kansalaistottelemattomuudesta (civil disobedience), jota toki hyödynnettiin muissakin liikkeissä Koijärveä myöten. Uutta 8o-luvulla oli myös se, että toimintamenetelmänä ja iskusanana kansalaistottelemattomuus levisi opiskelijoiden piiristä kansan keskuuteen. Idea kansalaistottelemattomuudesta korosti yksilön velvollisuutta olla noudattamatta moraalitonta lakia, mikä on tuttua monien väkivallatonta toimintaa korostaneiden suurmiesten elämästä Mohandas Gandhista Martin Luther Kingiin. (Keltti 1998, 18-19.)

Suomalainen rauhanliike sai uutta puhtia ydinaseiden vastaisesta liikkeestä ja taistolaisliikkeen degeneroitumisesta. Vuonna 1985 ilmestyi pitkän linjan pasifistin ja valtioopin emeritusprofessorin Göran von Bonsdorffin kirja 100 kysymystä rauhasta. Bonsdorff oli maltillisemman rauhantyön kannattaja, ja korosti "maailmanhallitusta" suvereenien valtioiden välisen rauhanyhteistyön sijaan. Kirjaa ruotiessaan Ylioppilaslehden Hannes Mäntyranta (1985b) kyseli, eikö suomalainen rauhaliike voisi lähteä ajamaan yhteiseurooppalaista yhteistyötä: "Miksei voi vaatia lisää kaasuputkia Siperiasta Eurooppaan. Miksei voi vaatia kaasuputkea Neuvostoliitosta Suomen kautta Ruotsiin? ja sitä rataa."

\section{Suomalaisessa julkisuudessa}

Miten 8o-luku suhteutuu Ylioppilaslehden satavuotiseen historiaan ajoittain merkittävänä suomalaisena julkisuusareenana? Ylioppilaslehden voi todeta pyrkineen noudattamaan ensimmäisenä puolivuosisatanaan habermasilaista ideaalia: porvarillista, normatiivista julkisuutta (Habermas 2004). Ylioppilaat edustivat Suomessa 6o-luvun suuriin ikäluokkiin saakka ensisijaisesti porvarillista eliittiä, jossa koulutettiin virkamiehiä korostamalla muun muassa retoriikkaa sekä yhteiskunnallista ja kulttuurista aktiivisuutta (ks. Klinge 1978; Kolbe 1990 \& 1996). Ylioppilaslehdillä, etenkin Ylioppilaslehdellä, on ollut oma tärkeä roolinsa tässä kansallisvaltioon valmentamisessa. 
Habermasilaiseen ideaaliin - jos ajatellaan sitä voitavan soveltaa myös 1700-luvun jälkeisiin yhteiskuntiin - viitatessa on kuitenkin hyvä tarkentaa, että Ylioppilaslehden kohdalla puhutaan osajulkisuudesta. Ylioppilaslehti on aina, mutta varsinkin alkuvuosinaan ollut ensisijaisesti osa toisen asteen julkisuuinstituutiota (Nieminen 2006, 30) eli yliopisto- ja ylioppilasmaailmaa. Pitkään kestäneen, Helsingin yliopiston suomalaistamiseen kulminoituneen kielitaistelun aikana lehti siirtyi kuitenkin myös päivittäiseen, ensimmäisen asteen julkisuuteen tai valtajulkisuuteen; se oli jo varsin merkittävä valtakunnallinen julkisuusareena 1920-30-luvuilla (ks. Kortti 2009).

Sotien jälkeinen Ylioppilaslehti kohosi Suomen merkittävimpiin kuuluvaksi kulttuurilehdeksi, jonka sivuilla määriteltiin esimerkiksi modernismia ja kulttuurikritiikkiä. Sen julkisuus oli tuolloin vieläkin lähimpänä normatiivista, feodalisoitumisesta vapaata ideaalia kuin alkuvuosikymmeninään: koska kyse oli paitsi porvariston keskinäisestä julkisuudesta, siinä myös määriteltiin hyvin elitistisesti esimerkiksi tradition ja modernin suhdetta sekä korkeakulttuurin estetiikkaa (ks. Kortti 2011b). 50-luku loi pohjaa 6o-luvun kansainvälisyyden mahdollistamalle uudenalaiselle moniarvoisuudelle. Julkinen keskustelu, jossa toteutuu deliberatiivisen demokratian ideaali, kuvaa kuitenkin vielä hyvin 6o-luvun alun radikalisoituvaa Ylioppilaslehteä: rajoittamatonta, yhteisymmärrykseen pyrkivää argumentoivaa puhetta, joka on vapaata ja muutoksen mahdollistaja.

Kun 6o-luvun radikaalit alkoivat tätä "porvarillista hegemoniaa" - käyttääksemme suosittua aikalaistermiä - kyseenalaistamaan, tilanne muuttui. 6o-luvun lopun liikehdintä oli jo niin monipuolista, ettei yksi lehti, kun sen päätoimittajaksikin valittiin maltillinen porvari (Yrjö Larmola), enää voinut toimia kaikkien suuntausten sateenvarjona. 6o-luvun liikehdintä oli luomassa eräänlaista "kaksoisdemokratian" julkisuutta, jossa demokraattinen julkisuus nojaa niin valtion lainsäädäntöön ja toimeenpanovaltaan, kuin kansalaisyhteiskuntaan. Viimeksi mainittuun ovat vaikuttaneet sodanjälkeiset liikkeet, kuten erilaiset vastakulttuuriliikkeet ja opiskelijaliike. (Malmberg 2009, 66-68.) Ylioppilaslehden sivuilla säilyi lehden perinteiden ja aseman vuoksi tietyltä osin normatiivisen deliberatiivisuuteen pyrkiminen, mutta kyse oli nyt myös agonistisesta, kiistelevästä moniarvoisesta julkisuudesta (Mouffe 2009), jossa oli voimakkaita vastakkainasetteluja.

70-luvun puoluepolitisoituminen hyydytti 6o-luvun kehityksen, jota haluttiin kelata eteenpäin nopeasti 8o-luvulla. Tosin Ylioppilaslehti ei enää yksin edustanut niin sanottuja vapaita medioita, vaan 8o-luku oli uudenlaisen kaupunkikeskeisen, puolueista riippumattoman mediakulttuurin syntyaikaa. Uutta urbaania lehdistöä oli pohjustanut 70-luvun lopulla syntynyt pienlehdistöbuumi, jolla oli vahvat siteet punk-kulttuuriin. Lähellä Ylioppilaslehteä niin aihepiireiltään kuin kirjoittajiltaan uusista 80-luvun lehdistä oli Suomi (1982-96). Myös vasemmistolaisen Uuden Laulun muututtua Alohaksi (198286), suomalainen kulttuurilehdistö astui uudenlaiseen, jälkimoderniin aikaan..$^{15}$

Yhteistä tälle uudelle medialle oli populaari- ja korkeakulttuurin rajalinjojen hävittäminen sekä se, että idealismi voitiin yhdistää kaupalliseen voitontavoitteluun. Yleisradiopolitiikkaan, mutta myös Ylioppilaslehden tapaiseen kulttuurilehteen kuulunut valistusajattelu hylättiin; median ei tarvinnut tarjota jokaiselle jotakin. Uudenlainen kaupunkimedia oli hyvin Helsinki-keskeistä, vaikka esimerkiksi City levisi myös paikallisina versioina isoimpiin Suomen kaupunkeihin (Isokangas ym. 2000, 112). 
Kun Ylioppilaslehti oli hukkumassa tähän uuteen mediamaisemaan, se vastasi - tiedostaen ja tiedostamatta - kahdella tavalla. Toisaalta lehti alkoi nojata puoluepolitiikan vaikutuksen vähentyessä ammattijournalismiin, toisaalta se etenkin 8o-luvun puolivälissä heittäytyi postmoderniin subjektivismiin, jossa pinta tuntui ajoittain olevan ainoa taso.

Ylioppilaslehti toteutti myös uudenlaista julkisuutta - tai julkisuuksia, jotka oli hankalaa mahduttaa habermasilaiseen ideaaliin. Yksi osa Habermas-kritiikkiä (esim. Calhoun 1992, 36-38; Frasier 115-116, 123; Ryan 1992, 283-286) on koskenut muun muassa sitä, ettei normatiivinen julkisuusteoria ole ottanut huomioon niitä monia julkisuuksia, jotka toteutuivat porvarillisen julkisuuden ulkopuolella. Sellaisia ovat esimerkiksi työväestön, feministien ja seksuaalivähemmistöjen julkisuudet. Ylioppilaslehti tarjosikin 8o-luvulla vastajulkisuusfoorumin erilaisille vaihtoehtoliikkeille ja feministeille. Tämä toteutui etenkin seksuaalivähemmistöjen esilletuomisessa (vrt. Warner 2005). Toki 6o-luvun radikalismi oli nostanut Ylioppilaslehden sivuille jo 6o-luvulla puolessa välissä kehitysmaat, feminismin, aseistakieltäytyjät, kirkon tekopyhyyden, huumeet ja seksin nuoren sivistyneistön keskusteltavaksi. Ärsyttäminen ja kyseenalaistaminen olivat oleellinen osa 6o-luvun radikalismia. Presidentti Kekkosta - joka antoi tukensa entiselle lehdelleen kun sen radikalismia kritisoitiin - eikä etenkään hänen johtamaansa ulkopolitiikkaa kuitenkaan juuri arvosteltu noottikriisin jälkeen.

\section{Konsensus-Suomea kyseenalaistamassa}

Tunnetussa kansainvälisten mediajärjestelmien analyysissä (Hallin \& Mancini 2004) Suomi on jaoteltu edustamaan yhdessä muiden pohjoismaiden kanssa demokraattiskoporatistista mallia, jossa valtio säätelee mediaa, mutta takaa sille myös suhteellisen vahvan itsenäisyyden. Hallinin ja Mancinin jaottelu on yleistyksenä tiettyyn pisteeseen asti toimiva, koska Suomessa on ollut esimerkiksi vahva puoluelehdistö ja yleisradioyhtiö. Suomen kohdalla malliin sopii myös suhteellisen varhainen journalistinen professionalisoituminen (emts. 173), jossa Ylioppilaslehdelläkin on ollut siis oma merkittävä roolinsa.

Suomi on kuitenkin siinä mielessä erikoistapaus, että niin sanotun toisen tasavallan (1944-1991) ja hyvinvointiyhteiskunnan luomisen aikana median itsenäisyyttä rajoittivat jossain määrin neuvostosuhteet. Lisäksi suomalainen älymystö on historiallisesti ollut aina läheisessä suhteessa valtioon - enemmän kuin esimerkiksi Ruotsissa. Sitä se on ollut myös 8o-luvun jälkeen. Konsensus-ajattelu on kuulunut oleellisesti snellmanilaiseen idealismiin jo 1800-luvun puolesta välistä lähtien (ks. Kortti 2011C). Älymystön ja valtion suhde ei ainakaan heikentynyt presidentti Kekkosen puuttuessa pitkällä kaudellaan melkein kaikkeen valtakunnassa, ennemminkin päinvastoin.

Tärkeää demokraattis-korporatistisessa mallissa on pyrkimys yhteiskunnalliseen konsensukseen, jota media edesauttaa (Hallin \& Mancini 2004, 50-53, 183-197). Sinällään idea ei ole mikään uusi. Stuart Hall (1992, 187-193) totesi jo 1980-luvun alussa viestinnän ideologisuutta käsitelleessä artikkelissaan, kuinka mediainstituutiot paitsi heijastavat, myös luovat yhteiskunnallista konsensusta, ja kuinka se koskee niin valtio-omisteisia kuin kaupallisia mediainstituutioita. Joka tapauksessa Hallinin ja Mancinin mallin mukai- 
nen konsensushakuisuus, jossa pyrkimys on päästä harkittuihin, koko yhteiskuntaa palveleviin ratkaisuihin, oli leimallista suomalaiselle yhteiskunnalle 8o-luvulle saakka. Tämä toteutui suomalaisessa mediassakin, vaikka poliittinen lehdistö oli vielä vahvaa ja ideologista. ${ }^{16}$ Toisaalta - jos ajatellaan demokraattis-korporatistinen malli deliberatiiviseen politiikkaan pyrkivänä järjestelmänä - ideaali deliberointi nojaa yleiseen hyvään eikä erityisintressien toteuttamiseen, vaikka ne saavutettaisiinkin kompromissien kautta (vrt. Malmberg 2012, 26).

8o-luvun Ylioppilaslehti pyrki omalta osaltaan ja hyvin tietoisesti rikkomaan konsensusta, jossa se itsekin oli ollut mukana etenkin "suomettumisen" kulta-aikana 70-luvulla. Keskustalaisten ja taistolaisten pääosin hallussa ollut lehti esimerkiksi noudatti maan virallista ulkopolitiikkaa, mikä ilmeni sen kulttuurisisällössäkin. Ylipäätään sotien jälkeisessä Suomessa kansallinen etu oli merkinnyt varovaisuutta ja itsesensuuria. On kuitenkin tärkeää olla suhtautumatta anakronisesti esimerkiksi 70-luvun journalismiin. Kuten viestinnän tutkijat (Christians ym. 2009, 18, 82) ovat todenneet, demokratiassa journalismi saattaa toisina aikoina olla enemmän vallan yhteistyökumppani, toisina aikoina enemmän radikaalien muutosten ajaja. Julkisen viestinnän normatiivinen teoria nousee tietystä yhteiskuntapoliittisesta kontekstista. Kun yhteiskunta organisoituu uudelleen, on julkinen viestinä osa sitä.

Tämä toteutuu esimerkiksi kyseenalaistamalla, kritisoimalla ja ironisoimalla vallanpitäjiä, joka oli mahdollista tai ainakin helpompaa Kekkosen jälkeisessä Suomessa. Toisaalta Ylioppilaslehdessä, kuten ajan nostamassa vastajulkisuudessa muutoinkin, myös tietynlaista mentaalista ja kulttuurista konsensusta haluttiin rikkoa antamalla tilaa vaihtoehtoliikkeille ja -ihmisille. Tämä yhdistyi 8o-luvun Ylioppilaslehdessä vielä ajoittain hyvin postmoderniksi muuttuneeseen subjektiiviseen ja narsistiseenkin journalismiin, jossa uuden journalismin omalla tavallaan omaksunut nuori toimittajakunta halusi välillä härnätä vain pönkittääkseen omaa egoaan.

\section{Viitteet}

$1 \quad$ Ylioppilaslehdestä yhteiskunnallisen sukupolven näkökulmasta tarkasteltuna ja median merkityksestä sukupolviliikkeissä ks. Kortti 2008 ja 2011 .

2 Enemmän Ylioppilaslehden historiasta Kortti (ilmestyy).

3 Kolportöörit olivat 180o-luvun Euroopassa kiertäviä esittäjiä, jotka tarjoilivat erilaista kansanomaista ajanvietettä.

4 Esimerkiksi 1800 -luvun puolenvälin painovapauden puuttuessa yhtäkin ylioppilasta saatettiin pitää "sanomalehtenä", joka liberaalin sanomalehdistön puuttuessa levittää "sähkölankana" aatteita maakuntiin (Klinge 1978, 56-57).

5 Lehtimiehistä puhuttiin noihin aikoihin yleisesti neekereinä, liittyen luultavammin painomusteeseen. Esimerkiksi Helsingin sanomalehtiyhdistys julkaisi vuonna 1946 kirjan Me Neekerit. Alastonta totuutta lehtimiehistä ja toimitustyön piiristä (Tikkanen 1946).

6 Esimerkiksi vuonna 1952 Ylioppilasneekerit aloittivat yhdessä Ylioppilaslehden kanssa kaksi lukukautta kestävät toimittajakurssit. Ylioppilasneekerit ja Ylioppilaslehti olivat myös vuonna 1953 suunnittelemassa toimittajakoulutuksen aloittamista vihdoin valtiotieteellisen tiedekunnan yhteyteen, mikä toteutui kevätlukukaudella 1954. Yhdistys oli laatinut ehdotuksen konsistorille sanomalehtiopin lehtorin virasta jo vuoden 1948 alussa. (Ylioppilaslehden johtokunnan pöytäkirjan lähtevä kirje Helsingin yliopiston konsistorille 24.2.1948.)

7 Kyseessä oli itse asiassa jo toinen "uusi journalismi". Ensimmäisen kerran termiä käytettiin 180o-luvun lopulla kaupallisen populaarilehdistön tavasta tehdä räikeitä sensaatiouutisia yms. 
"Suomettumisella", jonka määrittelemänä on edelleen kiistanalainen suomalaisessa historiantutkimuksessa, on yleisesti tarkoitettu aikaa noottikriisistä (1961) Neuvostoliiton romahdukseen (1991). Sen kehittelivät länsisaksalaiset konservatiivipoliitikot kuvaamaan suomalaistyylistä, YYA-sopimuksella Neuvostoliittoon sidottua politiikkaa, jossa pieni maa on tiukasti isomman vaikutuspiirissä niin ulko- kuin sisäpoliittisesti. Mediassa sen on katsottu toteutuneen itsesensuurina: vältettiin negatiivista kirjoittelua Neuvostoliitosta. Näkemykset eroavat karkeasti siinä, missä määrin toiminta katsottiin olleen taitavaa "reaalipolitiikkaa" vai "rähmällään oloa". Tässä yhteydessä "suomettumista" käsitellään lähinnä siten, miten se koettiin 80-luvulla. Suomettumisesta ks. esim. Vihavainen 1991 ja Bäckman 1999 ja erityisesti journalismissa Salminen 2004.

9 Radio Cityn perustamisen tärkein moottori Teppo Turkki muisteli, että he olivat olleet yhdessä Juha Hemánuksen kanssa tapaamassa Pertti Hemánusta ja toista Tampereen yliopiston tiedotusopin professoria ja yleisradioideologia Kaarle Nordenstrengiä. Tilanne oli kääntynyt klassiseksi isänmurhatilanteeksi: Juha oli huutanut isänsä huoneessa tälle, että "objektiivista todellisuutta ei ole olemassa". Tähän isä Hemánus oli huutanut takaisin, että "teidän pitäisi kunnioittaa meitä". Turkki puhuikin 8o-luvun alusta, johon Radio Cityn perustaminen kontekstualisoitui "uutena kulttuurimaisemana", jota luonnehti Kekkosen ajan päättyminen, edellisen vuosikymmenen lopulla aloittanut punk-liike, Koijärvi-liike, talonvaltausliike, elävänmusiikinyhdistykset, interrail-matkailu, Euroopan avautuminen ja yleinen laaja omaehtoinen kulttuuritoiminta. Aikalaiskommenteissaan Turkki halusikin puhua radio-aaltojen sijaan "tajunta-aallosta". (Radio-ohjelma Tapahtui 1985: Radio City, osa 1: Radiomonopoli murtuu.; Radio-ohjelma Tapahtui 1985: Radio City, osa 2: Tapaus Pekka Siitoin.)

$10 \quad$ Ks. esim. 'Rajansa kaikella' Kansan Uutiset 18.3.1985; Astikainen 1985.

11 "Koivistolaisen mediapolitiikan kompastelusta" presidentin ensimmäisellä kaudella ks. Suomi 2005, $550-563$.

12 Infokratiasta ja sitaattikiistasta ks. Salokangas 1996, 357-361; Pernaa 2009, 230-256.

13 Esimerkiksi Ylioppilaslehden yleisönosastolla eräs toinen Tuomas Manninen koki tämän jatkumona mannisten muutenkin "loukkaavaan" kohteluun kansanperinteessä tyyliin "iliman pilas itikoilla, maailman kaiken muaaliman mannisilla". (T. Manninen 1988.)

14 Harakasta tuli myöhemmin vihreiden pää-äänenkannattajan Vihreän Langan päätoimittaja. Hän sai potkut vuonna 1994 arvosteltuaan lehden presidenttistrategiaa, kieltäytyessään julkaisemasta puolueen järjestösivua ja kyseltyään puoluejohtajalta [Pekka Haavisto] tämän seksuaalisesta suuntautuneisuudesta. Ylioppilaslehti yhdisti Harakan erottamisen samoihin aikoihin tapahtuneeseen toimittaja Ruben Stillerin potkuihin YLEn Radio Mafiasta tämän kutsuttua YLEn johtajaa Kalervo Siikalaa "kökkötraktoriksi". Ylioppilaslehti katsoi Harakan yhteydessä, että "epävarmoina aikoina [9oluvun lama] yleinen erilaisuuden sietokyky vähentyy" ja "vihreys näyttää olevan kovaa vauhtia keskiikäistymässä ja omaksumassa vauhdilla samaa vallankäyttökulttuuria, jota se aikanaan niin kritisoi" (ks. Laitala 1994a; Laitala 1994b).

15 8o-luvun suomalaisten kulttuurilehtien "ensimmäisestä aallosta" ks. Tuusvuori 2007, 542-600.

16 Toisaalta Suomi on ollut kaupallisen television sekä satelliitti- ja kaapelitelevision pioneereja Euroopassa, joten Suomessa on ollut angloamerikkalaisia ja pluralistisia piirteitä ainakin television suhteen jo varhain (ks. Kortti 2003, Kortti 2007). Eroja muihin pohjoismaihin löytyy muitakin (ks. Herkman 2009b, 87). Itseään suhteessa valtioon määrittelevällä kaupallisella medialla on toki tärkeä asemansa Hallinin ja Mancinin demokraattis-korporatistisessa mallissa, muttei myöskään amerikkalainen "liberaali media" ole ikinä ollut säätelystä vapaata. Malleilla, jotka tavoittelevat "ideaalityyppiä", on tapana yksinkertaistaa ja tämän Hallin ja Mancinikin $(2004,12)$ toki tiedostavat.

\section{Kirjallisuus}

Bäckman, Johan (toim.) (1999) Entä kun tulee se yhdestoista? Suomettumisen uusi historia. Helsinki: WSOY

Calhoun, Craig (1992). Habermas and the Public Sphere. Teoksessa: Calhoun, Craig (toim.). Habermas and the Public Sphere. Cambridge, Massachusetts, London: The MIT Press, 1-48.

Christians, Clifford G. \& Glasser ,Theodore L. \& McQuail, Denis \& Nordenstreng, Kaarle \& White, Robert A. (2009). Normative Theories of the Media. Journalism in Democratic Societies. Urbana and Chicago: University of Illinois Press.

Fraser, Nancy (1992). Rethinking the Public Sphere: A Contribution to the Critique of Actually Existing Democracy. Teoksessa: Calhoun, Craig (toim.). Habermas and the Public Sphere. Cambridge, Massachusetts, London: The MIT Press, 109-142.

Habermas, Jürgen (2004). Julkisuuden rakennemuutos. Tutkimus yhdestä kansalaisyhteiskunnan kategoriasta (suom. Veikko Pietilä). Tampere: Vastapaino. 
Hakala, Salli (2011). Notkistuva politiikka Teoksessa: Kantola, Anu (toim.). Hetken hallitsijat. Julkinen elämä notkeassa yhteiskunnassa. Helsinki: Gaudeamus, 89-114.

Hall, Stuart (1992). Kun ideologia uudelleen keksittiin: Torjutun paluu tiedotustutkimukseen (suom. Kauko Pietilä). Teoksessa: Koivisto, Juha \& Lehtonen, Mikko \& Uusitupa, Timo \& Grossberg, Lawrence (toim.). Stuart Hall: Kulttuurin ja politiikan murroksia. Tampere: Vastapaino, 149-193.

Hallin, Daniel C. \& Mancini, Paolo (2004). Comparing Media Systems. Three Models of Media and Politics. Cambridge: Cambridge University Press.

Harakka, Timo (1998). Viemärirotta... mutta miksei Erkko ole vieläkään adoptoinut minua? Helsinki: Otava.

Hemánus, Pertti (1989). Viestinnän ja joukkotiedotuksen perusteet. Johdatus tiedotusoppiin I. Helsinki: Yliopistopaino.

Herkman, Juha (2009a). Journalismi markkinoilla, konserni- ja mediajournalismia. Teoksessa Väliverronen, Esa (toim.). Journalismi murroksessa. Helsinki: Gaudeamus, 32-49.

Herkman, Juha (2009b). The Structural Transformation of the Democratic Corporatist Model: The Case of Finland. Javnost - The Public 16: 4, 73-90.

Herkman, Juha (2011). Politiikka ja mediajulkisuus. Tampere: Vastapaino.

Isokangas, Antti \& Karvala, Kaappo \& von Reiche, Markus (2000). City on sinun. Kuinka uusi kaupunkikulttuuri tuli Helsinkiin. Helsinki: Tammi.

Kantola, Anu (2011). Notkean journalismin nousu Teoksessa: Kantola, Anu (toim.). Hetken hallitsijat. Julkinen elämä notkeassa yhteiskunnassa. Helsinki: Gaudeamus, 115-141.

Keltti, Juha (1998). Väkivallaton toiminta, sosiaalinen puolustus, yhteiskunnallinen muutos. Vaihtoehtojen hapuilua sodanjälkeisessä Suomessa. Teoksessa Raninen, Kaj (toim.). Katkelmia alistumisesta ja vastarinnasta. Helsinki: Aseistakieltäytyjäliitto ry, 5-23.

Kivistö, Sari (2011). Pekkarisen peruukki ja Isänmaan parturit: skandaali ja media poliittisen satiirin silmin. Teoksessa Dahlgren, Susanne \& Kivistö, Sari \& Paasonen, Susanna (toim.). Skandaali! Suomalaisen taiteen ja politikan mediakohut. Helsinki: Helsinki-kirjat, 143-169.

Kolbe, Laura (1993). Sivistyneistön rooli. Helsingin yliopiston ylioppilaskunta 1944-1959. Helsinki: Otava.

Kolbe, Laura (1996). Eliitti, traditio, murros. Helsingin yliopiston ylioppilaskunta 1960-199o. Helsinki: Otava.

Klinge, Matti (1978). Kansalaismielen synty. Ylioppilaskunnan historia 1853-1871 Helsinki: HYY ja Oy Gaudeamus Ab.

Kortti, Jukka (2003). Modernisaatiomurroksen kaupalliset merkit. 6o-Iuvun suomalainen televisiomainonta. Helsinki: SKS.

Kortti, Jukka (2007). Näköradiosta digiboksiin. Suomalaisen television sosiokulttuurinen historia. Helsinki: Gaudeamus.

Kortti, Jukka (2008). Ylioppilaslehden sotia edeltävät sukupolvet ja mediahegemonia. Ylioppilaan maailmankatsomusta jäljittämässä' Teoksessa Railo, Erkka (toim.). Ajankohta 2008. Sukupolvet historiassa. Poliittinen historia, Turun ja Helsingin yliopisto, 2008, 83-108.

Kortti, Jukka (2009). Ylioppilaslehti and the University's Language Struggle in the 1920's and the 1930's. Kasvatus Q Aika 3 (4)/2009, 7-73.

Kortti, Jukka (2011a). Generations and Media History. Teoksessa: Fortunati, Leopoldina \& Colombo, Fausto (toim.). Broadband Society and Generational Changes Series: Participation in Broadband Society - Volume 5. Frankfurt am Main, Berlin, Bern, Bruxelles, New York, Oxford, Wien: Peter Lang 2011, 69-93.

Kortti, Jukka (2011b). Building the New Cultural Finland. Student Magazine Ylioppilaslehti, Public Sphere and Creating Finnish Cultural Elite in Postwar Era. Scandinavian Journal of History 36: 4, 2011 462-478.

Kortti, Jukka (2011c). Suomalainen älymystö: aina valmiina valtion palvelukseen. Kanava 2/2011, 10-14.

Kortti, Jukka (ilmestyy 1/2013). Ylioppilaslehden vuosisata (työnimi). Helsinki: Gaudeamus.

Luostarinen, Heikki \& Turo Uskali (2006). Suomalainen journalismi ja yhteiskunnan muutos. Teoksessa Heiskala, Risto \& Luhtakallio, Eeva (toim.). Uusi jako. Miten Suomesta tuli kilpailukyky-yhteiskunta? Helsinki: Gaudeamus, 179-201.

Malmberg, Tarmo (2009). Lippmann vai Dewey? Demokratia, poliittinen kulttuuri ja julkisuus. Media Q Viestintä 32: $3,54-72$.

Malmberg, Tarmo (2012). Yleinen mielipide, viestintä ja kansanvalta: liberaalista deliberatiiviseen demokratiaan. Teoksessa: Karppinen, Kari \& Matikainen, Janne. Julkisuus ja demokratia. Tampere: Vastapaino, 15-36.

Mouffe, Chantal (2009). Keskusteleva demokratia vai kiistelevä moniarvoisuus? (Alkup. 'Deliberative democracy on agonistic pluralism?' Social Research 66:3, Fall 1999, 745-759) Media ja viestintä 32: 3, 45-53. 
Muhlmann, Géraldine (2008). A Political History of Journalism (käännös Jean Birrell ranskalaisesta alkuperäisteoksesta vuodelta 2004) Cambridge, Malden: Polity Press, 135-151.

Mäntylä, Jorma (2008). Journalistin etiikka. Helsinki: Gaudeamus.

Nieminen, Hannu (2006). Kansa seisoi loitompana. Kansallisen julkisuuden rakentuminen Suomessa 1809-1917. Tampere: Vastapaino

Pernaa, Ville (2009). Uutisista, hyvää iltaa. Ylen tv-uutiset ja yhteiskunta 1959-2009. Helsinki: YLE Karttakeskus.

Ryan, Mary P. (1992). Gender and Public Access: Women's Politics in Nineteenth-Century America. Teoksessa: Calhoun, Craig (toim.). Habermas and the Public Sphere. Cambridge, Massachusetts, London: The MIT Press, 259-288.

Salminen, Esko (2004). Viestinnällä vallankumoukseen. "Demokraattisen toimittajakoulutuksen" aika 1960-luvulta 1980-luvulle. Helsinki: Edita.

Salokangas, Raimo (1996). Aikansa oloinen. Yleisradion historia 1926-1996. Helsinki: WSOY

Suomi, Juhani (2005). Pysähtyneisyyden vuodet. Mauno Koiviston aika 1981-1984. Otava: Helsinki.

Tikkanen, Eino (1946). Sattuma ja journalistiikka. Teoksessa: Me Neekerit. Alastonta totuutta lehtimiehistä ja toimitustyön piiristä. Helsingin sanomalehtiyhdistys. Porvoo, Helsinki: WSOY.

Tuusvuori, Jaakko S. (2007). Kulttuurilehti 1771-2007. Helsinki: SKS.

Vihavainen, Timo (1991). Kansakunta rähmällään. Suomettumisen lyhyt historia. Helsinki: Otava Warner, Michael (2005). Publics and Counterpublics. New York: Zone Books.

Aineisto

\section{Lehdet}

Aleksanda K (1985). Politiikan vahtihauvat. Ylioppilaslehti 19/1985, 14-15.

Astikainen, Arto (1985). Varoittelu N-liiton piikittelystä ei merkitse lehdistön kuriinpanoa. Helsingin Sanomat 12.4.1985.

Ehrnrooth, Jari (1986). Makuuhalusta halun makuun. Ylioppilaslehti 11/1986, 13-15.

Grundström, Elina (1993). Suomen arvovaltaisin lastenlehti. Helsingin Sanomien Kuukausiliite 22/1993, 56-63.

Harakka, Timo (1983). Yhtä mieltä -yhdistyksen synkkä syysjamboree. Ylioppilaslehti 20/1983, 9.

Harakka, Timo (1984a). Mistä vihreitä kokoomukseen? Ylioppilaslehti 6/1984, 16.

Harakka, Timo (1984b). Mitä vittua. Ylioppilaslehti 24/1984, 19.

Harakka, Timo (1985). Vakaumuksesta vankilaan. Ylioppilaslehti 2/1985, 19.

Heino, Elina (1983). Mahtuvatko homot kirkkoon. Ylioppilaslehti 7/1983, 15.

Hemánus, Juha (1998). Humanismin hirttäjäiset. Ylioppilaslehti 1/1988, 7.

Hemánus, Pertti (1983). Pierua. Ylioppilaslehti 18/1983, 5.

Hirvonen, Maarit (1981). Uusi journalismi pohtii todellisuuden olemusta. Ylioppilaslehti 1/1981, 6.

Hyvönen, Eero (1986). Lapsi on monityydyttäjä. Ylioppilaslehti 11/1986, 2-5.

Hänninen, Marja \& Rutanen, Anna (1985). Tehtävän hekuma. Ylioppilaslehti 24/1985, 17-18.

Kantola, Anu (1988). Ei mikään suuren tehtävän ideologi. Ylioppilaslehti 2/1988, 8-9.

Kirstinä, Kari (1985). Sydänyön tuolla puolen. Ylioppilaslehti 24/1985, 16.

Kontio, Kari (1983). Contemporary Problems of Objective Journalism. Ylioppilaslehti 17/1983, 20.

Kontio, Kari \& Mäntyranta, Hannes (1986). SDP - likainen petos. Ylioppilaslehti 6/1986, 13-16.

Laitala, Marko (pääkirjoitus) (1994a). Ristivetoa mediakentällä. Ylioppilaslehti 2/1994, 2.

Laitala, Marko (1994b). Vihreiden kriitikko. Ylioppilaslehti 2/1994, 6-7.

Lindfors, Jorma (1980). Kaikki ei ole gonzoa, mikä kiitää. Ylioppilaslehti 13/1980, 4-5.

Lähteenmaa, Jaana (1984). Muistakaa joka akka. Ylioppilaslehti 24/1984, 14-15.

Manninen, Martti (1988). Tasavallan Presidentin virallinen haastattelu. Ylioppilaslehti 1/1988, 8-9.

Manninen, Tuomas (1988). Mannisia loukattu. Ylioppilaslehti 4/1988, 12.

Mattila, Marketta (1988). Saska Saarikoski ja 75-vuotias Ylioppilaslehti "Me olemme vakavia".' Uusi Suomi 20.10.1988.

Mäkelä, Johanna (1986). Pornografiaa ja selviytymisstrategiaa. Ylioppilaslehti 11/1986, 17-18. 
Mäntyranta, Hannes (1985a). Nykyinen ulkopolitiikka: Pelkkää perinteen vaalimista. Ylioppilaslehti 21/1985, 4-6. Mäntyranta, Hannes (1985b). Rauhanliike jakaa kahteen. Ylioppilaslehti 22/1985, 14-15.

Nyberg, Pertti (1986). Kuolleiden kaupunki. Ylioppilaslehti 11/1986, 23.

Pääkirjoitus. (1984a). Uudet patut. Ylioppilaslehti 11/1984, 5.

Pääk. (1984b). 'Käen poika' YL 18/1984, 7.

Pääk. (1985a). Niin internationaalia niin internationaalia. Ylioppilaslehti 5/1985, 5.

Pääk. (1985b). Pitkän iän salaisuus. Ylioppilaslehti 8/1985b, 7.

Pääk. (1985c). Tosipaikan tullen. Ylioppilaslehti 24/1985, 2.

Pääk. (1987). Presidentin perspirantti. Ylioppilaslehti 8/1987, 2.

Pääk. (1988). Koivisto ja Syvä Kuilu. Ylioppilaslehti 3/1988, 2.

Pääk. (nimim. TM) (1989). 'Nuorena nukkuneet. Ylioppilaslehti 14/1989, 3.

Nevanlinna, Tuomas (1986). Journalismista käytävä keskustelu. Ylioppilaslehti 24/1986, 8-9.

Palmgren, Pekka (1980). Mitä on Gonzo-journalismi? Ylioppilaslehti 20/1980, 12.

Pietinen, Kimmo (1983). Laaja-alaisesti: Jorma. Ylioppilaslehti 4/1983, 16.

Pietinen Kimmo (1984a). Myrskyn silmässä. Ylioppilaslehti 18/1984, 14-15.

Pietinen, Kimmo (1984b). Kuka särkee ikkunoita? Ylioppilaslehti 1/1984b, 2.

Pyörälä, Eeva (1986). Intohimon riivaamana. Ylioppilaslehti 11/1986, 6-7.

Rutanen, Anna (1985). Suu auki! Suu kiinni!. Ylioppilaslehti 24/1985, 17.

Saarikoski, Saska (1985). Puolimatkan krouvi. Ylioppilaslehti 4/1985, 18-19.

Saarikoski, Saska (2010). Kekkosen lapset mediaa mylläämässä. Helsingin Sanomat 31.10.2010, C2.

Saukkomaa, Harri \& Turkki, Teppo (1982). Presidentti Mauno Koivisto: Vaihtoehtoliikkeet ovat tulevain heijastuksia. Ylioppilaslehti 21/1982, 3-4.

Savolainen, Juha (1986). Älymystölehden pohjat: Ylioppilaslehti lokajournalismin suossa. Suomen Sosialidemokraatti 12.3.1986.

Schildt, Christine (1984). Kuka hän on? Ylioppilaslehti 11/1984, 10.

Siimes, Suvi-Anne (1986). Valkoiset varjot. Ylioppilaslehti 11/1986, 5.

Suvanto, Pertti (1981). Toimittajakoulun priimus: Journalismi kaipaa kokeiluja. Ylioppilaslehti 1/1981, 7.

'Teatterikoulu esittää: Sorsa Pariisissa' Ylioppilaslehti 6/1986, 11.

Tirkkonen, Jarko (1985). Mikä mies, mikä maa. Ylioppilaslehti 10/1985, 10.

Tunkkari, Heikki (1988). Nopeasti tuloksiin tähtäävää tutkimusta. Ylioppilaslehti 2/1988, 8-9.

Turkki, Teppo (1982). Ylioppilaslehti 21/1982, 3.

Väliverronen, Esa (1984). Syökö seksuaalinen vallankumous lapsensa. - Vai onko aikamme ahtaampi. Ylioppilaslehti 24/1984, 13.

Ylioppilaslehden reportterikurssin opettaja ja oppilaat tyytyväisiä. Ylioppilaslehti 26/1947, 3.

Ylioppilaslehti 21/1987, 11.

Ytterström (1984). Jälkeen Vagina Lollofrdigan. Ylioppilaslehti 18/1984, 7.

Ytterström (1985a). Hyppösellinen ainetta. Ylioppilaslehti 5/1985, 5.

Ytterström (1985b). Lisänä Afrikka Rokissa. Ylioppilaslehti 8/1985, 7.

\section{Painamattomat lähteet}

Helsingin yliopiston ylioppilaskunnan (HYY) vuosikertomus 1986 (painamaton).

\section{Haastattelut}

Kimmo Pietisen haastattelu 15.4.2004, haastattelija Lauri Paavola.

Saska Snellmanin haastattelu 12.6.2008, haastattelija Jukka Kortti.

\section{TV-ohjelmat}

Ajankohtainen kakkonen TV 2 14.2.1989, SITA-ote.

\section{Radio-ohjelmat}

Tapahtui 1985: Radio City, osa 1: Radiomonopoli murtuu. Toimittaja Tapio Pajunen. YLE Puhe 2010. Tapahtui 1985: Radio City, osa 2: Tapaus Pekka Siitoin. Toimittaja Tapio Pajunen. YLE Puhe 2010. 